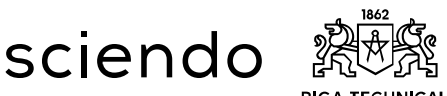 \\ RIGA TECHNICAL}

ISSN: 2255-9671 (online)

$2019,7,18-29$

doi: 10.2478/bjreecm-2019-0002

https://content.sciendo.com

\title{
EUROPEAN PROJECTS OF COMMON INTEREST: IMPACT ON FUEL AND ENERGY MARKETS IN POLAND
}

\author{
Grzegorz KUNIKOWSKI
}

\author{
Faculty of Management, Warsaw University of Technology, Warsaw, Poland \\ Corresponding author's e-mail:Grzegorz.Kunikowski@pw.edu.pl
}

\begin{abstract}
Projects of common interest are projects serving the implementation of priority corridors and areas of energy infrastructure, mainly trans-European electricity, gas and oil transmission networks in order to reduce the European Union's energy dependence. They also help strengthen the energy security of individual countries, including Poland. The article aims at reviewing projects and assessing an impact on domestic markets in the context of the challenges of the fuel and energy sector in Poland. The article is an analytical study, in the "desk research" formula. Research methods used during the elaboration of the research include the analysis of national and EU strategic documents and the subject matter of energy security. In order to evaluate the impact of the implementation of projects of common interest on a variety of supplies of a member country (Poland), an exemplary assessment of the diversification status is presented using Hirschman-Herfindahl concentration index for gas supplies.
\end{abstract}

Keywords: Energy security, index Hirschman-Herfindahl, projects of common interests.

\section{INTRODUCTION}

For a modern state, energy security and sustainability of fuel and energy supplies are the conditions for stable economic development. The presence of Poland in the structures of the European Union means the possibilities of energy market integration, participation in solidarity mechanisms, and thus increasing its own security. On the other hand, it is associated with the necessity of implementation of the energy and climate policy, which is a priority for the European Union, and due to the high share of fossil fuels in Poland, in particular hard coal and lignite, it is not fully in line with a national energy policy regarding costs of structural rebuilding of the energy system.

The international guidelines of the European Commission underline the role of solidarity mechanisms among the Member States in terms of gas and oil reserves and the protection of energy infrastructure. The importance of cooperation and integration of internal electricity, gas and oil markets will also be emphasised, including building key interconnectors, reducing energy demand, diversifying supplies, reducing imports and strengthening own production with the use of new technologies (EC, 2008).

A practical dimension of political declarations is the implemented infrastructure projects that significantly and permanently enable the integration of 
markets and the implementation of interconnections. These projects have the status of Project of Common Interest (PCI), and the list is created periodically in a time correlation with EU investment funding programmes, based on the established initiatives (e.g., international clusters) and consultation and evaluation procedure.

The genesis of the definition of infrastructure projects is strategic analyses carried out at the request of the European Commission, which specifies the needs of corridors for electricity, oil and gas $(\operatorname{COM}(2010) 677,2010)$.

One of the main objectives of implementation of PCI is to improve diversification of energy fuel supplies. In order to estimate the diversification state, being constantly monitored, Hirschman-Herfindahl concentration index (HHI) can be used.

The article aims at reviewing projects and assessing an impact on domestic markets in the context of the challenges of the fuel and energy sector in Poland.

\section{RESEARCH METHODS}

The article is an analytical study, in the "desk research" formula, based on the analysis of the national and EU strategic documents and the subject matter of energy security.

In order to perform an analytical study, the analysis of the directions of development of the national fuel and energy sector has been conducted. Legal issues and the perspective of energy companies defining strategic risks have also been taken into account. Then, the current list of Projects of Common Interest has been presented.

Based on the results, an example of quantitative assessment of the significance of PCI for Poland's energy security by HHI index has been presented.

\section{RESULTS}

\subsection{National Regulations and Strategies}

In the field of fuel and energy, the national legislation sets strategic directions in the Energy Law Act (Dz. U. 2017 poz. 220, tekst jednolity, z późn. zm., 1997).

In the field of energy security, the key provisions are compulsory provisions (Dz. U. $2007 \mathrm{nr} 52$ poz. 343, 2007). In the field of renewable energy sources, the RES Act should be quoted (Dz. U. 2015 poz. 478, z późn. zm., 2015), the regulations regarding biofuels and biocomponents, including those concerning quality (Dz. U. z 2014 r. poz. 1643 z późn. zm., 2006; Dz. U. 2006 nr 169 poz. 1200 z póź. zm., 2006). Energy efficiency issues are regulated (Dz. U. 2016 poz. 831, 2016).

The legislation adopted in recent years concerns power market and electromobility issues (Dz. U. 2018 poz. 9, 2018; Dz. U. 2018 poz. 317, 2018).

Due to the difficulties in formulating assumptions regarding the condition of the energy sector, the document entitled Energy Policy of Poland until 2030 (ME, 2009) deserves a special attention. The draft on the Energy Policy of Poland until 2040 is being consulted (PEP 2040, 2018). 


\subsection{Examples of the Identified Strategic and Operational Risks at Energy Companies}

The Energa Capital Group, in the operational area concerning the continuity of fuel and energy supplies, defines the following risks:

- Occurrence of random events such as: failures, weather anomalies, atmospheric factors or the actions of third parties

They can affect the safety and continuity of electricity production and supply with appropriate quality parameters to recipients. The indicators of this risk in the distribution area are SAIDI and SAIFI indicators ${ }^{*}$. In the production area, in turn, there are data regarding deviations from production plans, as well as indicators informing about the number of failures / events limiting availability or duration of failures / events limiting availability. In order to protect it, a high degree of regulation of this area has been introduced.

- Failures of manufacturing devices and auxiliary installations

The effects of this risk materialization include failure to meet the terms of sales agreements and production plans, while not meeting the requirements set out in the integrated permit and environmental regulations. To reduce this risk, it is planned to implement IT systems supporting production management and implementation of modernization investments of basic generation devices ${ }^{\dagger}$.

The Capital Group 'Polska Grupa Energetyczna' (PGE) presents the following strategic risks for the annual report:

- Technological revolution - the risk of technological change causing deterioration of the profitability of electricity and heat production in system sources and their distribution by means of network assets being the responsibility of the PGE Group.

- Competition - the risk of development of a product offered by the competition (also from outside the energy sector) affecting the reduction of the Group's share in the energy market.

- The forces of nature - the risk of increasing the occurrence of extreme weather conditions.

- Occupational health and safety - the risk of unexpected events bringing irreparable material losses and serious injuries or deaths of people.

- Cybersecurity - the risk of intentional disruption of the proper functioning of the processing and information exchange space created by the IT systems operating in the PGE Group.

- Human resources - the risk of limiting the availability of employees, which is crucial from the point of view of processes carried out in the PGE Group.

- Law - the risk arising from the instability and breadth of the law that defines the rules of the Group's operations.

- Policy - the risk of changes in the vision of development of the energy sector.

* SAIDI - System Average Interruption Duration Index. SAIFI - System Average Interruption Frequency Index.

${ }^{\dagger}$ Based on: http://raportroczny.energa.pl/obszary-ryzyka.html accessed 21.08.2018. 
- Environmental restrictions - the risk of tightening environmental restrictions related to the production of electricity and heat as well as conducting mining operations.

- Macroeconomics - the risk of a negative change in the economic situation and fluctuations in the level of macroeconomic indicators determining the Group's operations

It can be seen that concerns about technological change (it should be assumed that it is about the development of RES technologies, i.e., low-emission solutions that can become competitive) regarding group's activities are considered a serious risk and supported by political will ("the risk of changes in the vision of the energy sector development"); the strengthened argumentation of environmental restrictions is the most important threat. In the category of current business risk for which three gradual scales of assessment have been adopted (risk: low, medium, high), four high risks have been identified ${ }^{\S}$ (out of 27 identified) and all relate to issues concerning emissions and environmental protection requirements (formal requirements and prices of emission allowances, $\mathrm{CO}_{2}$, BAT requirements) ${ }^{* *}$.

\subsection{Energy Policy and Project of Common Interest - The Perspective of Poland}

The draft on the Energy Policy of Poland until 2040 (PEP 2040) presents the eight appropriate strategic directions, namely:

1) Optimal use of own energy resources;

2) Development of electricity generation infrastructure and network infrastructure;

3) Diversification of gas and oil supplies and development of network infrastructure;

4) Development of energy markets;

5) Implementation of nuclear energy;

6) Development of renewable energy sources;

7) Development of district heating and cogeneration;

8) Improvement of energy efficiency of the economy.

The document is a project that is subject to consultation. Regardless of the final status of the policy, we clearly see the importance of developing the network infrastructure of electricity, gas, oil and heating.

Cross-border networks are also crucial from the point of view of the energy security of the countries of the European Union.

Strategic EU initiative with the status of Project of Common Interest:

1) Priority Corridor Northern Seas Offshore Grid ('NSOG');

\footnotetext{
\$ Based on: http://raportzintegrowany2016.gkpge.pl/pl/rozwoj/ryzyka/ryzyka-strategiczne accessed 21.08.2018.

$\S$ High risk has been characterised as follows: intolerable risk requiring immediate and active reaction to risk, aimed at simultaneous reduction of possible effects and the likelihood of its occurrence.

** Based on: http://raportzintegrowany2016.gkpge.pl/pl/rozwoj/ryzyka/ryzyka-biezacej-dzialanosci accessed 21.08.2018.
} 
2) Priority Corridor North-South Electricity Interconnections in Western Europe ('NSI West Electricity');

3) Priority Corridor North-South Electricity Interconnections in Central Eastern and South Europe ('NSI East Electricity');

4) Priority Corridor Baltic Energy Market Interconnection Plan ('BEMIP Electricity');

5) Priority Corridor North-South Gas Interconnections in Western Europe ('NSI West Gas');

6) Priority Corridor North-South Gas Interconnections in Central Eastern and South Eastern Europe ('NSI East Gas');

7) Priority Corridor Southern Gas Corridor ('SGC');

8) Priority Corridor Baltic Energy Market Interconnection Plan in Gas ('BEMIP Gas');

9) Priority Corridor Oil Supply Connections in Central Eastern Europe ('OSC');

10)Priority Thematic Area Smart Grids Deployment;

11)Priority Thematic Area Electricity Highways.

Table 1. The List of the Projects of Common Interest in Poland (developed by the author, based on EC, 2017a; EC, 2017b)

\begin{tabular}{|c|c|}
\hline Project of Common Interest / Clusters of PCIs & Priority Corridor \\
\hline $\begin{array}{l}\text { Internal reinforcements in Poland [part of the cluster currently } \\
\text { known as "GerPol Power Bridge"], including the following } \\
\text { PCIs: } \\
\text { 3.14.2 Internal line between Krajnik and Baczyna (PL) } \\
\text { 3.14.3 Internal line between Mikułowa and Świebodzice (PL) } \\
\text { 3.14.4 Internal line between Baczyna and Plewiska (PL) }\end{array}$ & $\begin{array}{l}\text { Priority Corridor North-South } \\
\text { Electricity Interconnections in } \\
\text { Central Eastern and South } \\
\text { Europe ("NSI East } \\
\text { Electricity") }\end{array}$ \\
\hline 4.5.2 Internal line between Stanisławów and Ostrołęka(PL) & $\begin{array}{l}\text { Priority Corridor Baltic } \\
\text { Energy Market } \\
\text { Interconnection Plan } \\
\text { ("BEMIP Electricity") }\end{array}$ \\
\hline $\begin{array}{l}\text { Interconnection between Poland, Slovakia, the Czech } \\
\text { Republic and Hungary with the related internal } \\
\text { reinforcements, including one or more of the following PCI } \\
\text { groups: } \\
\text { 6.2.1 Poland-Slovakia interconnection } \\
\text { 6.2.2 North-South Gas Corridor in Eastern Poland } \\
\text { and } \\
\text { 6.2.10 Poland-Czech Republic interconnection [currently } \\
\text { known as "Stork II"] } \\
\text { 6.2.11 North-South Gas Corridor in Western Poland } \\
\text { 6.2.12 Tvrdonice-Libhoš' pipeline, including upgrade of CS } \\
\text { Břeclav (CZ), } \\
\text { and the following PCIs: } \\
\text { 6.2.13 Increase of the transmission capacity at the Slovakia- } \\
\text { Hungary interconnection }\end{array}$ & $\begin{array}{l}\text { Priority Corridor North-South } \\
\text { Gas Interconnections in } \\
\text { Central Eastern and South } \\
\text { Eastern Europe ("NSI East } \\
\text { Gas") }\end{array}$ \\
\hline
\end{tabular}




\begin{tabular}{|c|c|}
\hline Project of Common Interest / Clusters of PCIs & Priority Corridor \\
\hline $\begin{array}{l}\text { 6.2.14 Enhancement of the Hungarian transmission system } \\
\text { between Vecsés and Városföld required for the increased } \\
\text { capacity at the Slovakia-Hungary interconnection }\end{array}$ & \\
\hline $\begin{array}{l}\text { Cluster infrastructure, including the following PCIs: } \\
\text { 8.3.1 Reinforcement of Nybro-Poland/Denmark } \\
\text { Interconnection } \\
\text { 8.3.2 Poland-Denmark interconnection [currently known as } \\
\text { "Baltic Pipe"] }\end{array}$ & $\begin{array}{l}\text { Priority Corridor Baltic } \\
\text { Energy Market } \\
\text { Interconnection Plan in Gas } \\
\text { ("BEMIP Gas") }\end{array}$ \\
\hline $\begin{array}{l}\text { 8.5 Poland-Lithuania interconnection [currently known as } \\
\text { "GIPL"] }\end{array}$ & $\begin{array}{l}\text { Priority Corridor Baltic } \\
\text { Energy Market } \\
\text { Interconnection Plan in Gas } \\
\text { ("BEMIP Gas") }\end{array}$ \\
\hline $\begin{array}{l}\text { 8.7 Capacity extension of Świnoujście LNG terminal in } \\
\text { Poland }\end{array}$ & $\begin{array}{l}\text { Priority Corridor Baltic } \\
\text { Energy Market } \\
\text { Interconnection Plan in Gas } \\
\text { ("BEMIP Gas") }\end{array}$ \\
\hline $\begin{array}{l}\text { 9.1 Adamowo-Brody pipeline: pipeline connecting the JSC } \\
\text { Uktransnafta's handling site in Brody (Ukraine) and } \\
\text { Adamowo Tank Farm (Poland) }\end{array}$ & $\begin{array}{l}\text { Priority Corridor Oil Supply } \\
\text { Connections in Central } \\
\text { Eastern Europe ("OSC") }\end{array}$ \\
\hline $\begin{array}{l}\text { Cluster Pomeranian pipeline (Poland), including the following } \\
\text { PCIs: } \\
\text { 9.5.1. Construction of oil terminal in Gdańsk (phase II) } \\
\text { 9.5.2. Expansion of the Pomeranian pipeline: the second line } \\
\text { of the pipeline }\end{array}$ & $\begin{array}{l}\text { Priority Corridor Oil Supply } \\
\text { Connections in Central } \\
\text { Eastern Europe ("OSC") }\end{array}$ \\
\hline
\end{tabular}

Poland is involved in priorities 3, 4, 6, 8, 9 (details - Table 1).

\subsection{The Assessment of Supply Diversification}

The structure of a given fuel and energy market can be assessed in the category of competitiveness and concentration, which is associated with diversification. A market that is diversified can be considered safe. For example, for the electricity, gas and oil market, Hirschman-Herfindahl Concentration Index (HHI) and Concentration Index (CRn) are used.

Herfindahl-Hirschman index (HHI) is defined as the sum of squares of the individual market shares of all the enterprises forming a given branch (Kamiński, 2009):

- HHI > 5000 - very high concentration;

- HHI from 1800 to 5000 - high concentration;

- HHI from 750 to 1800 - medium concentration;

- less than 750 - low concentration.

Concentration factor $\mathrm{CRn}$ is the index of market share of n-largest entities. In Poland, the CR3 indicator is used, measured according to the energy introduced into the network by the 3 largest suppliers.

Both mentioned indices (HHI and CRn) for Poland are applied by the President of the Energy Regulatory Office in cyclical reports and serve as the characteristics of the entity structure of the wholesale electricity market (URE, 2018, pp. 45-47). 
Other indices are also used in scientific publications, taken from general methods of the market structure analysis. For instance, the analysis of the Croatian energy market concentration includes Hall-Tideman index (HTI), Entropi index (H), Landes-Posner index (LP) and the HHI and CR indices mentioned earlier (Banovac, 2005, pp. 249-256).

Other examples of the use of Herfindahl-Hirschman index (HHI) and its modification:

- assessment of concentration on the global gas market (Kryzia, 2010, pp. 539-555);

- modified HHI for the consideration of additional aspects such as import and export capabilities, economic and political stability; detailed results from the review are provided (Bożyk, 2013);

- Hall-Tideman index (HTI) (Hall \& Tideman, 1967) is a modification of the HHI index. The index is more sensitive to the number of entities than their shares.

Shannon-Wiener Index (SWI) also puts more emphasis on small entities operating on the market, which is used to measure the degree of diversification of primary energy suppliers, fuel. The discussion of both indices (SWI and HHI) together with the developed CERE index (Contribution to EU Risk Exposure) is presented by Le Coq i Paltseva (Le Coq \& Paltseva, 2009).

The biggest advantage of the HHI index is that with the use of fairly easily available data and after performing simple mathematical calculations, it allows for a sufficient determination of the level of concentration of production and an indication of the proper structure of the examined market. The main drawback of the HHI index should be the inability to include factors unrelated to production I sales, such as the impact of limited energy transmission capacity in a given region, specific market strategies for producers, or the adoption of similar strategies with selected other producers (Kamiński, 2009, p. 235).

\subsection{An Example of the Use of the HHI Indicator to Assess the Effects of Selected PCI Projects on the Example of Natural Gas}

In the draft on the Energy Policy of Poland until 2040 (PEP 2040, 2018), one of the eight directions of the sector development in the perspective of 20 years is diversification of supplies and development of network infrastructure. Poland remains largely dependent on natural gas supplies from abroad, mainly from the east, also as part of supplies from Germany and the Czech Republic (in 2017, $78 \%$ of consumed natural gas came from imports, $52 \%$ - from the east.

Current annual gas import capacity, measured by the technical capacity of cross-border connections, is 53 billion $\mathrm{m}^{3}$ (Table 2 ). 
Table 2. Capacity for Natural Gas Import in Perspective in 2016, in Billion $\mathrm{m}^{3}$ (developed by the author, based on GAZ-SYSTEM, 2016, p. 9; 20; URE, 2018, pp. 183-184)

\begin{tabular}{|l|r|r|}
\hline \multicolumn{1}{|c|}{ Entry points } & Capacity, billion $\mathbf{~ m}^{\mathbf{3}}$ & \multicolumn{2}{c|}{ Capacity, \% } \\
\hline Kondratki & 30.7 & 57.9 \\
\hline Drozdowicze & 4.4 & 8.3 \\
\hline Malnow & 5.4 & 10.2 \\
\hline Wysokoje & 5.5 & 10.4 \\
\hline Cieszyn & 0.5 & 0.9 \\
\hline GCP Gaz- & 1.5 & 2.8 \\
System/Ontras & 5 & 9.4 \\
\hline Terminal LNG & $\mathbf{5 3}$ & $\mathbf{3 7 3 3 . 5 7}$ \\
\hline ALL & \multicolumn{2}{|c|}{} \\
\hline HHI & \multicolumn{2}{|c|}{} \\
\hline
\end{tabular}

For the given data, the HHI index is 3734, which means a high concentration. It should be remembered that the indicator refers to technical capacity, whose annual value $\left(53\right.$ billion $\mathrm{m}^{3}$ ) exceeds the annual consumption, which in 2017 amounted to over 17 billion $\mathrm{m}^{3}$, and the capacity is used for gas transit (Tables 2-3).

Table 3. Contracted Purchase of Natural Gas in 2017 (developed by the author, based on URE, 2018, p. 211)

\begin{tabular}{|l|r|r|}
\hline \multicolumn{1}{|c|}{ Contract } & ${\text { Purchase, billion } \mathbf{~ m}^{\mathbf{3}}}$ & Purchase, \% \\
\hline $\begin{array}{l}\text { PGNIG SA - Gazprom } \\
\text { Export }\end{array}$ & 9.39 & 54.18 \\
\hline PGNIG SA - UE & 2.29 & 13.21 \\
\hline PGNIG SA - other (LNG) & 1.63 & 9.41 \\
\hline Own supply & 4.02 & 23.20 \\
\hline ALL & $\mathbf{1 7 . 3 3}$ & $\mathbf{1 0 0 . 0 0}$ \\
\hline HHI & \multicolumn{2}{|c|}{} \\
\hline
\end{tabular}

The value of the concentration factor calculated for the contracted deliveries amounted to 3849 , which means a high concentration of suppliers.

Assuming the implementation of investment plans, including PCI projects in 2020, the capacity will increase by gas connections included in the list of PCI projects (Table 1). Table 4 presents the planned import capacity after completing the PCI investment in 2022 according to the plans of the GAZ-SYSTEM operator. 
Table 4. Planned Capacity for Natural Gas Import in Perspective of 2022, in Billion $\mathrm{m}^{3}$ (developed by the author)

\begin{tabular}{|c|c|c|c|c|c|}
\hline \multirow[t]{2}{*}{ Entry points } & \multirow[t]{2}{*}{ PCI } & \multicolumn{2}{|c|}{ Variant with transit } & \multicolumn{2}{|c|}{ Variant without transit } \\
\hline & & $\begin{array}{l}\text { Capacity, } \\
\text { billion } \mathbf{m}^{3}\end{array}$ & $\begin{array}{c}\text { Capacity, } \\
\%\end{array}$ & $\begin{array}{l}\text { Capacity, } \\
\text { billion } \mathbf{m}^{3}\end{array}$ & $\begin{array}{c}\text { Capacity, } \\
\%\end{array}$ \\
\hline Kondratki & & 30.7 & 38.3 & & \\
\hline Drozdowicze & & 4.4 & 5.5 & & \\
\hline Malnow & & 6.1 & 7.6 & 6.1 & 15.4 \\
\hline Wysokoje & & 5.5 & 6.9 & & \\
\hline Cieszyn & & 0.5 & 0.6 & 0.5 & 1.3 \\
\hline $\begin{array}{l}\text { GCP Gaz- } \\
\text { System/Ontras }\end{array}$ & & 1.5 & 1.9 & 1.5 & 3.8 \\
\hline Terminal LNG & & 5 & \multirow[b]{2}{*}{9.4} & 5 & \multirow[b]{2}{*}{19.0} \\
\hline $\begin{array}{l}\text { Terminal LNG - } \\
\text { rozbudowa }\end{array}$ & 8.7 & 2.5 & & 2.5 & \\
\hline Baltic Pipe & 8.3 .2 & 10 & 12.5 & 10 & 25.3 \\
\hline Słowacja & 6.2 .1 & 5.7 & 0.0 & 5.7 & 0.0 \\
\hline $\begin{array}{l}\text { Czechy Hat } \\
\text { (Stork II) }\end{array}$ & 6.2 .10 & 6.5 & 8.1 & 6.5 & 16.5 \\
\hline Litwa & 8.5 & 1.7 & 2.1 & 1.7 & 4.3 \\
\hline ALL & & 80.1 & & 39.5 & \\
\hline HHI & & & 1972.71 & & $\mathbf{1 7 5 3 . 5 0}$ \\
\hline
\end{tabular}

We can see that regardless of the use of transit capabilities (entry points Kondratki, Drozdowicze, Wysokoje), the implementation of the PCI investment results in reduction of the HHI index to 1973 or 1754, which means that the concentration is moderate. For the "transit" case, HHI being equal to 1973 means high concentration, but it is the value from a lower range ${ }^{\dagger \dagger}$.

\subsection{Qualitative Assessment of PCI Project Impact}

The PCI priorities grouped into energy and fuel sectors may have an impact not only on Poland but on the region. Table 5 presents characterisation of the selected corridors.

${ }^{\dagger}$ With regard to previously cited vales, HHI between 1800 and 5000 means high concentration. 
Table 5. Impact of PCI Investment on Polish and International Energy Markets (developed by the author)

\begin{tabular}{|c|c|c|c|c|}
\hline \multirow{2}{*}{$\begin{array}{l}\text { Energy } \\
\text { Sector }\end{array}$} & \multirow{2}{*}{ PCI } & \multirow{2}{*}{ Relevance } & \multicolumn{2}{|r|}{ Influence } \\
\hline & & & Scope & Justification \\
\hline \multirow[t]{2}{*}{ Gas } & $\begin{array}{l}\text { Priority Corridor North-South } \\
\text { Electricity Interconnections in } \\
\text { Central Eastern and South } \\
\text { Europe ("NSI East } \\
\text { Electricity") } \\
\text { (connections between Poland } \\
\text { and the systems of Slovakia, } \\
\text { the Czech Republic, the } \\
\text { eastern and western directions) }\end{array}$ & $\begin{array}{l}\text { Strengthening } \\
\text { the security } \\
\text { of supply }\end{array}$ & $\begin{array}{l}\text { Key } \\
\text { for the } \\
\text { region }\end{array}$ & $\begin{array}{l}\text { The scale of the } \\
\text { project is } \\
\text { international, and the } \\
\text { implementation } \\
\text { concerns the region of } \\
\text { Europe }\end{array}$ \\
\hline & $\begin{array}{l}\text { Priority Corridor Baltic } \\
\text { Energy Market } \\
\text { Interconnection Plan in Gas } \\
\text { ("BEMIP Gas") } \\
\text { (connections with Denmark, } \\
\text { extension of the LPG terminal) }\end{array}$ & $\begin{array}{l}\text { Strengthening } \\
\text { the security } \\
\text { of supply }\end{array}$ & $\begin{array}{l}\text { Key } \\
\text { for } \\
\text { Poland }\end{array}$ & $\begin{array}{l}\text { Although the scale of } \\
\text { the project is regional, } \\
\text { implementation } \\
\text { means diversifying } \\
\text { sources of gas supply, } \\
\text { whose consumption } \\
\text { will increase. }\end{array}$ \\
\hline \multirow[t]{2}{*}{ Electricity } & $\begin{array}{l}\text { Internal reinforcements in } \\
\text { Poland [part of the cluster } \\
\text { currently known as "GerPol } \\
\text { Power Bridge"], }\end{array}$ & $\begin{array}{l}\text { Improvement } \\
\text { of quality }\end{array}$ & $\begin{array}{l}\text { Key } \\
\text { for } \\
\text { Poland }\end{array}$ & $\begin{array}{l}\text { Improvement of } \\
\text { quality and security of } \\
\text { supply. }\end{array}$ \\
\hline & $\begin{array}{l}\text { Priority Corridor Baltic Energy } \\
\text { Market Interconnection Plan } \\
\text { ("BEMIP Electricity") }\end{array}$ & $\begin{array}{l}\text { Improvement } \\
\text { of quality, } \\
\text { Strengthening } \\
\text { the security } \\
\text { of supply }\end{array}$ & $\begin{array}{l}\text { Key } \\
\text { for } \\
\text { region }\end{array}$ & $\begin{array}{l}\text { Improvement of } \\
\text { quality and security of } \\
\text { supply. Increasing the } \\
\text { balancing possibilities } \\
\text { in the regional system. }\end{array}$ \\
\hline Oil & $\begin{array}{l}\text { Priority Corridor Oil Supply } \\
\text { Connections in Central } \\
\text { Eastern Europe ("OSC") } \\
\text { (pipeline to Ukraine, extension } \\
\text { of the terminal in Gdansk with } \\
\text { a pipeline) }\end{array}$ & $\begin{array}{l}\text { Strengthening } \\
\text { the security } \\
\text { of supply }\end{array}$ & $\begin{array}{l}\text { Key } \\
\text { for } \\
\text { Poland }\end{array}$ & $\begin{array}{l}\text { The project means } \\
\text { diversification of } \\
\text { crude oil supplies and } \\
\text { deepening integration } \\
\text { with the energy } \\
\text { system of Ukraine. }\end{array}$ \\
\hline
\end{tabular}

The above-mentioned assessment indicates the key importance of projects, and that their implementation will contribute to improvement of the country's energy security. It is clear that the technological issue is not a direct objective of PCI projects related to natural gas and crude oil. In terms of electricity, they improve quality, but also enable deeper integration and balancing possibilities. This is connected not only with the created clusters, but with a low-emission economy and the use of renewable energy. The examples of risks of the mentioned energy companies indicate the benefits of implementing projects in the field of neutralization of the effects of technical failures. 


\section{CONCLUSION}

The assessment of importance of PCI projects into Poland's energy security has been made through a qualitative (descriptive) approach supported by justification and indication of the scale of impact crucial for Poland or the region. The quantitative assessment has been based on the example of gas supplies using the HHI concentration index. The results clearly show that the implementation of crossborder gas connection projects will technically enable diversification of gas supplies to Poland. The results clearly demonstrate that the implementation of cross-border gas connection projects will technically enable diversification of gas supplies to Poland. The PCI investments in natural gas infrastructure will result in reduction of the HHI concentration index from the value of 3734 to 1973 or 1754 (where values depend on the analysed variant - with transit or without transit), which means the change in concentration from high to moderate. The development of infrastructure should be accompanied by strategic contracts that will allow for full diversification of supplies. In the case of electricity, PCI projects influence not only the quality and continuity of service for destined customers and technical efficiency but also improve the balancing of the power system. Traditional energy companies in Poland consider technological changes as a serious risk rather than a chance for development. Thus, the growing share of weather dependent RES installations is of increasing importance for balancing capabilities of national power systems.

\section{ACKNOWLEDGMENT}

The article is the result of the research for a project financed by the National Centre for Research and Development entitled "Highly Specialized Platform Supporting Civil Emergency Planning and Rescue in the Polish Public Administration and Organizational Units of the National Firefighting and Rescue System", agreement DOB - BIO7/11/02/2015 implemented by the consortium: Warsaw University of Technology (Faculty of Management), Medcore sp. z o.o.

\section{REFERENCES}

Banovac, E. (2005). Measuring concentration in the energy markets. Nafta, 56(6), 249-256.

Bożyk, P. (Ed.). (2013). Bezpieczeństwo energetyczne Polski w ujęciu autonomicznym $i$ zintegrowanym z Unia Europejska. Warszawa: Akademia Finansów i Biznesu Vistula.

$\operatorname{COM}(2010)$ 677. (2010). Energy infrastructure priorities for 2020 and beyond - A Blueprint for an integrated European energy network.

Dz. U. z 2014 r. poz. 1643 z późn. zm. (2006). Ustawa z 25 sierpnia 2006 r. o biokomponentach i biopaliwach ciekłych.

Dz. U. 2006 nr 169 poz. 1200 z póź. zm. (2006). Ustawa z dnia 25 sierpnia 2006 r. o systemie monitorowania i kontrolowania jakości paliw.

Dz. U. 2007 nr 52 poz. 343. (2007). Ustawa z dnia 16 lutego 2007 r. o zapasach ropy naftowej, produktów naftowych i gazu ziemnego oraz zasadach postępowania w sytuacjach zagrożenia bezpieczeństwa paliwowego państwa i zakłóceń na rynku naftowym.

Dz. U. 2015 poz. 478, z późn. zm. (2015). Ustawa z dnia 20 lutego 2015 r. o odnawialnych źródłach energii.

Dz. U. 2016 poz. 831. (2016). Ustawa z dnia 20 maja 2016 r. o efektywności energetycznej.

Dz. U. 2017 poz. 220, tekst jednolity, z późn. zm. (1997). Ustawa z dnia 10 kwietnia 1997 r. - Prawo energetyczne. 
Dz. U. 2018 poz. 9. (2018). Ustawa z dnia 8 grudnia 2017 r. o rynku mocy.

Dz. U. 2018 poz. 317. (2018). Ustawa z dnia 11 stycznia 2018 r. o elektromobilności i paliwach alternatywnych.

EC. (2008). Council Directive 2008/114/EC of 8 December 2008 on the identification and designation of European critical infrastructures and the assessment of the need to improve their protection. Official Journal of the European Union, L.345/75.

EC. (2017a). Commission Delegated Regulation (EU) 2018/540 of 23 November 2017 amending Regulation (EU) No 347/2013 of the European Parliament and of the Council as regards the Union list of projects of common interest. Official Journal of the European Union, L 90/38.

EC. (2017b). The list of the projects of common interest (PCIs) by country - the (third) Union list of PCIs. Brussels: European Commission. Retrieved from https://ec.europa.eu/energy/sites/ener/files/documents/memberstatespci_list_2017.pdf

GAZ-SYSTEM. (2016). Krajowy dziesięcioletni plan rozwoju systemu przesyłowego; Plan rozwoju $w$ zakresie zaspokojenia obecnego i przyszłego zapotrzebowania na paliwa gazowe na lata 20162027, Wyciag. Warszawa: GAZ-SYSTEM S.A. Retrieved from http://www.gazsystem.pl/fileadmin/pliki/open-season/Krajowy_Dziesiecioletni_Plan_Rozwoju_2018-2027.pdf

Hall, M., \& Tideman, N. (1967). Measures of Concentration. Journal of the American Statistical Association, 62(317), 162-168. https://doi.org/10.1080/01621459.1967.10482897

Kamiński, J. (2009). Metody szacowania siły rynkowej w sektorze energetycznym. Polityka Energetyczna, T. 12, z. 2/2, 229-241.

Kryzia, D. (2010). Analiza zmian koncentracji na światowym rynku gazu ziemnego. Wiertnictwo, Nafta, Gaz, T. 27, z. 3, 539-555.

Le Coq, C., \& Paltseva, E. (2009). Measuring the security of external energy supply in the European Union. Energy Policy, 37(11), 4474-4481. https://doi.org/10.1016/j.enpol.2009.05.069

ME. (2009). Polityka energetyczne Polski do 2030 roku. Warszawa: Ministerstwo Gospodarki.

PEP 2040. (2018). Polityka Energetyczna Polski do 2040 roku - projekt. Warszawa: Ministerstwo Energii.

URE. (2018). Sprawozdanie z działalności Prezesa Urzędu Regulacji Energetyki w 2017 r. Warszawa: Urząd Regulacji Energetyki.

\section{AUTHORS' SHORT BIOGRAPHY}

Grzegorz Kunikowski received the title of Doctor of Economics in the management discipline in 2015 from the Faculty of Management at Warsaw University of Technology. He has experiences of participation in national and international research projects in the field of civil planning, crisis management and renewable energy.

ORCID iD: https://orcid.org/0000-0002-3660-7117 